\title{
Population bases and the 2011 Census
}

Steve Smallwood

Office for National Statistics

\begin{abstract}
In an increasingly complex society there are a number of different population definitions that can be relevant for users, beyond the standard definition used in counting the population. This article describes the enumeration base for the 2011 Census and how alternative population outputs may be produced. It provides a background as to how the questions on the questionnaire were decided upon and how population bases can be constructed from the Census. Similarities and differences between the information collected across the three UK Censuses (England and Wales, Scotland and Northern Ireland) are discussed. Finally, issues around estimating the population on alternative bases are presented.
\end{abstract}




\section{Introduction}

In an increasingly complex society there are a number of different definitions that may be relevant to users of population statistics. These include people who live in an area most of the time (resident population), people who work in an area, or who only spend some of their time there. Definitions relate to both who is counted in the population and where geographically those people are counted. An article in 2004 in Population Trends highlighted some of the issues about choosing the enumeration base, discussed what might be collected in the 2011 Census and summarised decisions about enumeration bases for the 1981, 1991 and 2001 Censuses $^{1}$. The article also highlighted that the Census can be enumerated on a 'persons present' basis and/or a 'usual residence' basis. It also pointed out that the population base at enumeration and that for output may be different. In 2006 a further article discussed many of the issues around population bases and the different potential definitions that could be used ${ }^{2}$.

Building on the two articles referred to above, and a previous article about questions to be asked in the 2011 Census $^{3}$, this article brings together the thinking behind the design of the questions used to define the population, both in terms of the enumeration base and defining the geography of the population. It also covers differences in design between the three Censuses in the United Kingdom. Where possible the Census operations and questions are harmonised as planned in the agreement between the National Statistician and the Registrars General ${ }^{4}$. There remain a few instances where, for policy and operational reasons, some differences remain. Finally, it discusses issues around making population estimates on different bases. Table 1 provides a summary of the bases that will be produced. At present there are no plans to produce annual population estimates on alternative bases, and some of the reasons for this decision are explained here.

It is worth noting that decisions about enumeration bases are not solely about compatibility with the outputs that are required. The design of the enumeration base also needs to ensure that everyone is counted who is required for the output, so may be wider than the required output to ensure that no one is missed.

\section{The 2001 Enumeration base}

The 2001 Census outputs throughout the UK were based on 'self-assessed' usual residence. The lead instruction on the 2001 questionnaire said 'list all members of your household who usually live at this address ... include anyone who is temporarily away from home on the night .... but who usually lives at this address.' The phrase 'usually lives' was not defined anywhere on the questionnaire. Within the detailed guidance material produced for the 2001 Census, there was reference to a 'six-month rule'. However, the number of census respondents who were aware of, and influenced by, this guidance definition of 'usually resident' is likely to have been negligibly small. Thus in practice the 2001 Census used self assessed usual residence for respondents ${ }^{5}$. The 2001 Census six month definition differs from the usual residence definition for mid-year population estimates which is those that have been, or are intending to be, in the country for 12 months or more, and those abroad for less than 12 months. It was assumed in 2001 that the numbers in the UK for between 6 and 12 months, and the numbers abroad for between 6 and 12 months, were broadly similar and therefore the actual difference in numbers would be small. 
The 2001 enumerated base was then adjusted for under enumeration (those who should have been counted but were not) using a capture recapture statistical process to produce an estimated count of the usual resident population. It is, therefore, possible that in a complex and mobile population some people did not complete a Census questionnaire, and were also not identified in the Census Coverage Survey (CCS), as they did not fit what they considered to be the definition of a 'usual resident'. Although the capture recapture model makes an estimate of people missed by both the Census and the CCS, it cannot include people who explicitly do not consider themselves to be usually resident ${ }^{3}$. They may not have defined themselves as a usual resident because they were living temporarily at an address which they did not consider to be their usual address but had no other address; or, although they had been, or intended to be, in the country for more than six months they did not consider themselves resident. These issues were recognised in subsequent adjustments made to England and Wales mid-year estimates following local authority studies and other analysis ${ }^{6}$.

\section{Table $1 \quad$ Population bases for the 2011 Census}

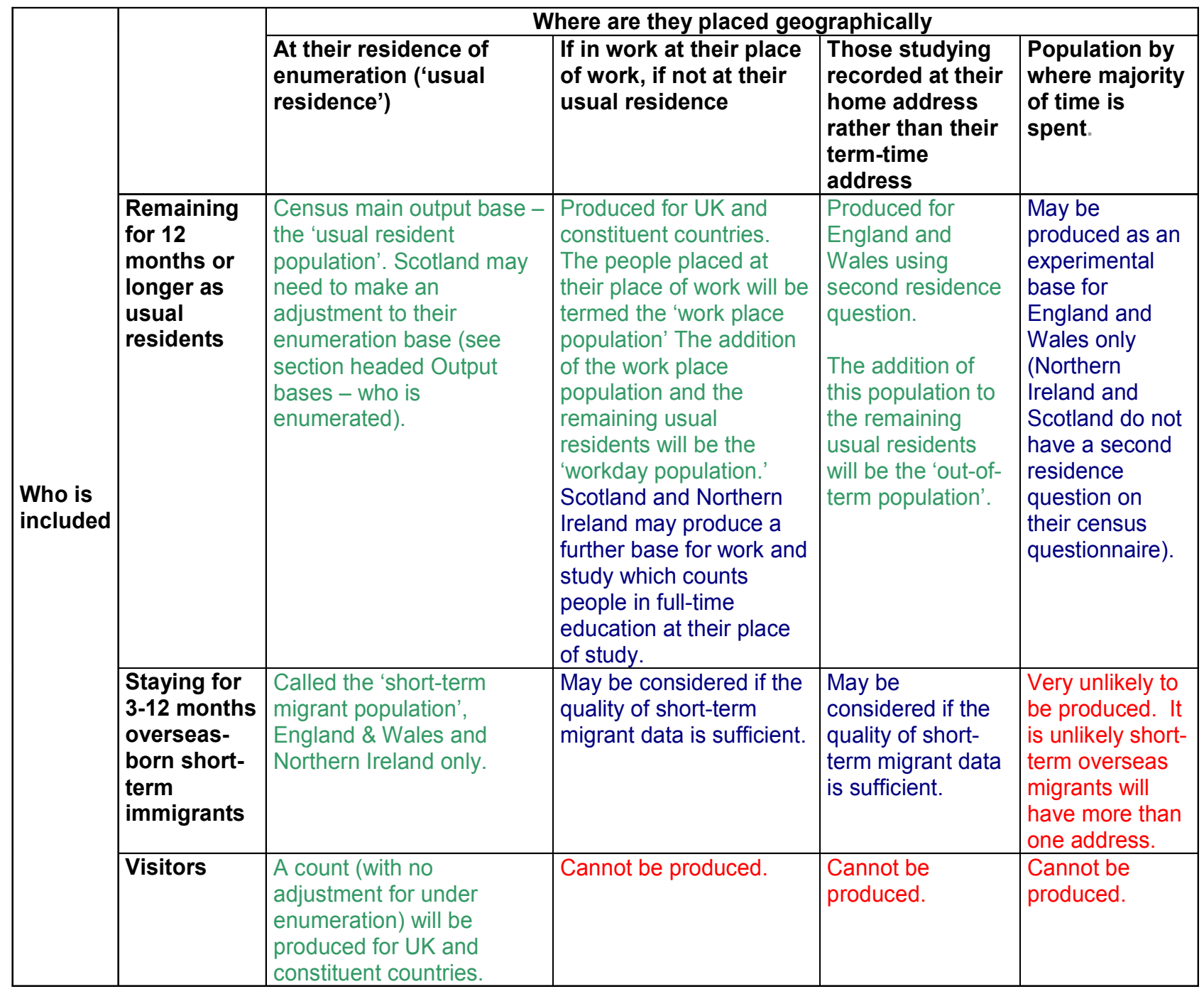

Key: Green=will be produced Blue=may be produced Red =will not be produced 


\section{The 2011 Enumeration base - who is enumerated?}

\section{England and Wales and Northern Ireland}

The 2011 Census will, like the 2001 Census, be adjusted for under enumeration so that full estimates of the population, on whatever base, can be produced ${ }^{7}$. The 2011 Census questionnaire has been designed to record: usual residents; short-term immigrants (in England and Wales and Northern Ireland); and visitors.

\section{Figure 1 Instructions on 2011 Census as to who should complete the questionnaire, England, Wales and Northern Ireland}

\section{Who should complete this questionnaire?}

The householder is responsible for ensuring that this questionnaire is completed and returned.

The householder is the person who lives, or is present, at this address who:

- owns/rents (or jointly owns/rents) the accommodation; and/or

- is responsible (or jointly responsible) for paying the household bills and expenses

A household is:

- one person living alone; or

- a group of people (not necessarily related) living at the same address who share cooking facilities and share a living room or sitting room or dining area

\section{What should you complete on this questionnaire?}

- Household questions on pages 3-6 about this household and its accommodation

- Individual questions on pages 7-30 for every person who usually lives in this household. Every person who has been, or intends to be, in the UK for 3 months or more should be included in these questions at their usual UK address

- Visitor questions on the back page (page 32) for all other people staying overnight in this household on 27 March 2011

It is important to include visitors staying overnight in this household to make sure no-one is missed. Visitors who usually live elsewhere in the UK must also be included on a census questionnaire at their usual address.

You will find further information about who to include in this questionnaire on page 31.

Questionnaires are delivered to addresses to be completed for everyone in that household on Census night. If there is more than one household at an address then more than one questionnaire will be needed. The household questionnaire begins with a set of instructions defining a household and explaining who should complete the questionnaire (Figure 1). These instructions clearly state that anyone intending to be in the country for three months or more should be fully enumerated. This can be termed the enumeration base. However, visitors are also being counted and a limited amount of information on them collected. So, in effect, the 2011 Census has components of both 'usual residence' and 'population present' enumeration bases. The definition of a household in 2001 with more than one person was a group of people (not necessarily related) living at the same address with common housekeeping - sharing either a living room or sitting room, or at least one meal a day. This has been modernised, and made less ambiguous, by the removal of the term 'common-housekeeping' (essentially a social definition) and based purely on the physical definition of shared kitchen and living space. It is therefore worded in a way that is easier to interpret for those in multi-occupied dwellings (see Figure 1$)^{3}$. 
The first question on the questionnaire is a tick list of all the people to be enumerated on the Census questionnaire. Figure 2 shows this for England, but it is the same for Wales and Northern Ireland. The purpose of this list is to ensure that no-one is missed.

\section{Figure $2 \quad 2011$ Census question determining who should be fully enumerated; England, Wales and Northern Ireland}

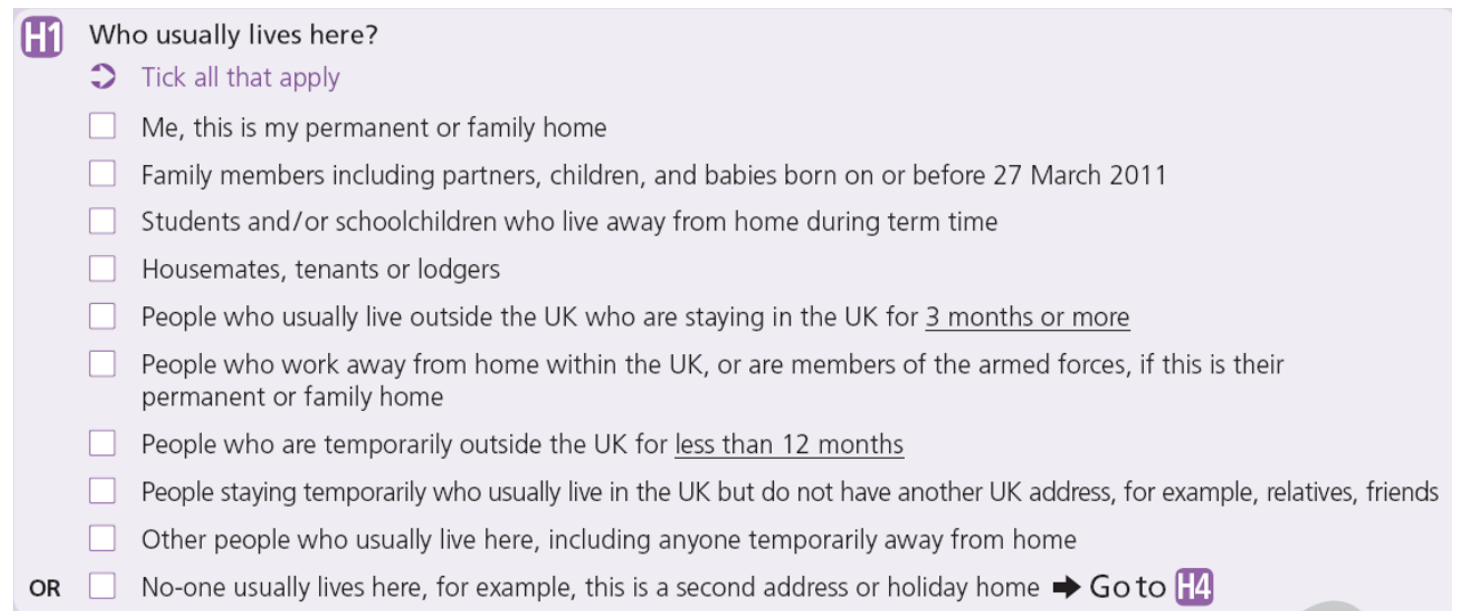

In particular, it includes the reminder to enumerate those who are temporarily outside the UK for less than 12 months. It should be possible to enumerate these people if there are other members of their household still present. Wholly absent households may be more difficult to capture. However, some such households will be estimated as these households will be enumerated in either the Census or the CCS. There will be some that are included in the Census but will have subsequently left and become absent and therefore will not be captured in the coverage survey. Some households will be absent at the time of the Census but will have returned to be captured in the CCS. Both situations will serve to inflate the dual system estimator and impute households representing those wholly absent households.

The 'who usually lives here?' question also reminds people to include those who have no other 'usual' UK address. Testing has shown answering this question helps ensure respondents include everyone they are required to, and addresses a perceived issue with the 2001 definitions: in 2001 it was thought some people may not have been enumerated because they did not consider where they were living to be their 'usual residence', even though they had no other.

Similar information is provided on the questionnaires for communal establishments.

\section{Scotland}

Scotland have chosen an enumeration base of six months or longer but have a similar question to the other UK countries, as shown in Figure 3. Scotland does not consider short-term migrants (those resident 3 to 6 months) to be a major issue and therefore preferred to keep a similar definition to that used in 2001. There is discussion later in the article on the production of a 12 month plus usual residence definition for Scotland. 


\title{
Figure 3 Instructions on 2011 Census as to who should complete the questionnaire and question determining who should be enumerated, Scotland
}

\author{
Who should fill in this questionnaire? \\ The householder or joint householder is responsible for filling in this questionnaire for their \\ household. \\ The householder or joint householder is the person who lives, or is present, at this address who: \\ - owns or rents (or jointly owns or rents) the accommodation; and / or \\ - is responsible (or jointly responsible) for paying the household bills and expenses.

\section{A household is:} \\ - one person living alone; or \\ - a group of people (not necessarily related) living at the same address who share cooking facilities \\ and share a living room or sitting room or dining area.
}

If there is more than one household at this address, please see the section below.

H1 Who usually lives here?

If you need more advice about who to include, see the extra guidance on page 3 or contact us.

- Tick all that apply.

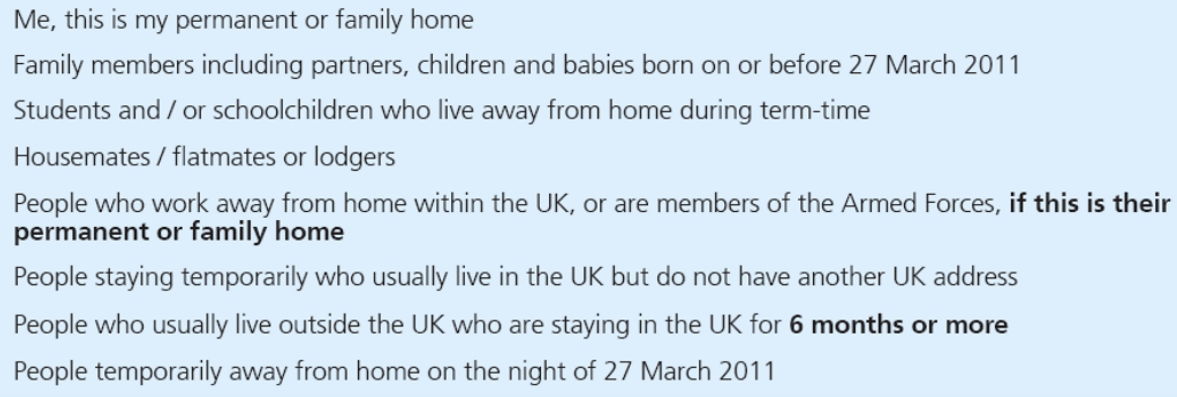

Scotland also collect the number of visitors, with basic information on age, sex and usual address recorded.

\section{Output bases - who is included?}

For England and Wales, and also for Northern Ireland, two output bases covering who is counted can be produced. The first is the 'usual residence' base for those present, or intending to be present, for 12 months or longer. The second is overseas short-term immigrants who are, or intend to be, present for between 3 and 12 months. Figure 4 shows the questions that will be used to divide the enumeration base into these two output bases from the England and Wales questionnaires.

In Northern Ireland similar questions are asked, but the question about arrival comes after the question on length of stay. This question immediately follows the question on country of birth, and only those born outside the UK are filtered to answer it. It contains the phrase 'If you arrived to live in the United Kingdom:' and then the options 'on or after 27 March 2010' and 'before 27 March 2010 ', with the former directing respondents to the intended length of stay question. 


\section{Figure 42011 Census questions to split short-term and long-term migrants, England and Wales}

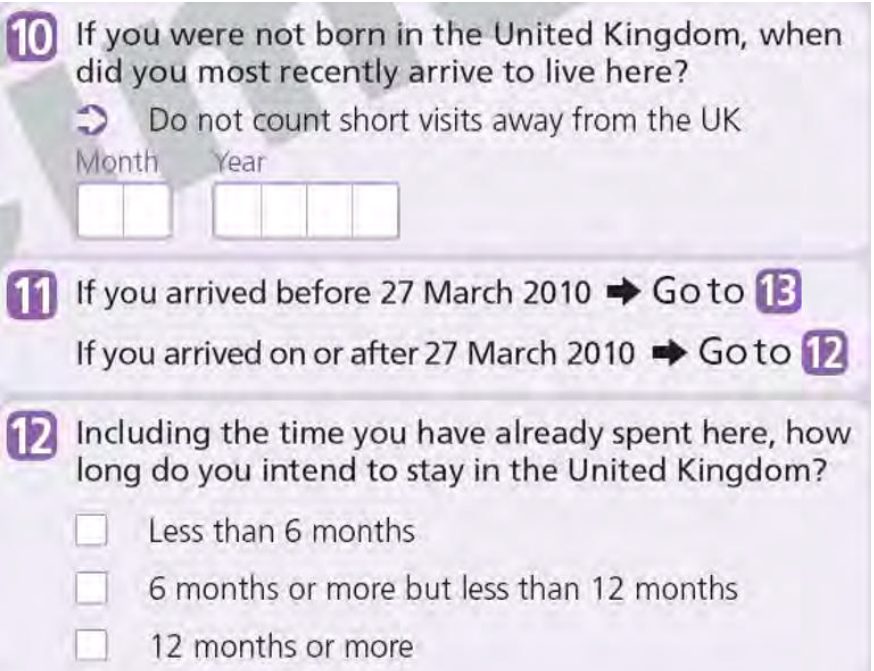

Scotland will not be able to produce a short-term immigrant base. Scotland is committed to producing a 12 month or longer population base from their enumeration base. There are potentially two adjustments that may be needed to their Census enumeration base. The first is removing those from abroad who are in the UK for 6 months or more but less than 12 months. Conversely, they have no specific instruction on the questionnaire to enumerate those UK residents who are abroad for less than 12 months - the check list simply refers to those who are temporarily away from home. So potentially some UK residents abroad may need to be added in. A decision will be taken in Scotland on what adjustments, if any, are needed later in the Census process.

The enumerated resident population in all the UK Censuses will be adjusted for non response. In addition to the estimates for the two enumeration output bases mentioned above, a count will also be produced of visitors. No estimation will be made of missed visitors, so this count will only be indicative of the number and geographical spread of visitors. The primary purpose of collecting information on visitors is to ensure that everyone is counted. Work will be carried out on a sample of visitors with a UK resident address to ensure they were correctly enumerated at their home address.

\section{Geographical output bases planned from the 2011 Census and questions that allow their derivation}

Having divided the estimated population into the usual residence base and - for England, Wales and Northern Ireland - overseas short-term immigrants, consideration can be given to where geographically these people might be placed.

For the main usual residence base respondents will be placed where they are fully enumerated ${ }^{8}$.

Moving from the Census usual residence base to that required for mid-year estimates may also require some small adjustments relating to Armed Forces. These may be needed as small changes that have been made to the enumeration definition could lead to larger than expected changes in the distribution of Armed Forces. For Armed Forces, the mid-year estimates generally 
aim to count people where they spend the majority of their time, unless they have a partner in which case they are enumerated with that partner. However, in the Census some Armed Forces personnel without a partner may be enumerated at their family address. The need for any adjustment will be assessed before mid-2011 estimates based on the 2011 Census are published. This is discussed further in Box 1.

\section{Box $1 \quad$ Armed Forces Enumeration}

In the 2001 Census, Armed Forces personnel with a partner (either a spouse or person with whom they cohabited) were enumerated at the place of residence of their partner. The intention was for other Armed Forces personnel to be enumerated at their base. In the 2011 Census the instructions ask that the following are enumerated in households: 'People who work away from home within the UK, or are members of the armed forces, if this is their permanent or family home' (see Figure 2).

The above change has the potential to see more Armed Forces personnel enumerated away from their base. However, analysis of 2001 data suggests that many Armed Forces members were enumerated at their family home address. In Scotland around 30 per cent of those not partnered were enumerated in households where they were not the head of the household, and in England and Wales around 30 per cent of those not partnered were found to live in a different local authority from where they worked. This suggests that respondents connected with the Armed Forces may have in fact been using an informal definition in 2001 closer to that of 2011.

The 2011 Census results will be examined to see if these proportions are substantially different. No adjustment will be made to the Census results, but ONS, GROS and NISRA will consider whether an adjustment is needed to the Census figures that are used as a base for the midyear population estimates.

\section{The following bases are included in Census production plans:}

\section{Workplace and Workday population}

The workplace population is defined as the population based on workplace location for those in employment. It will be produced for the usually resident population; that is, those resident, or intending to be resident, in the UK for 12 months or more. Effectively, it is a geographical redistribution of the usually resident population who are in work to their place of work. There may be interest in applying this geographical redistribution to those in the overseas short-term immigrant base to provide a work place population based on the entire enumeration base. This will only be considered once the quality of the overseas short-term immigrant base is assessed.

The workday population is the workplace population plus those usually resident in an area who are not in work. Information is collected in the Census on place of work in the question shown in Figure 5. Scotland and Northern Ireland are collecting additional information on place of study in their equivalent question. Examples are shown in Figure 6. 


\section{Figure 5 Work place address question, 2011 Census, England and Wales}

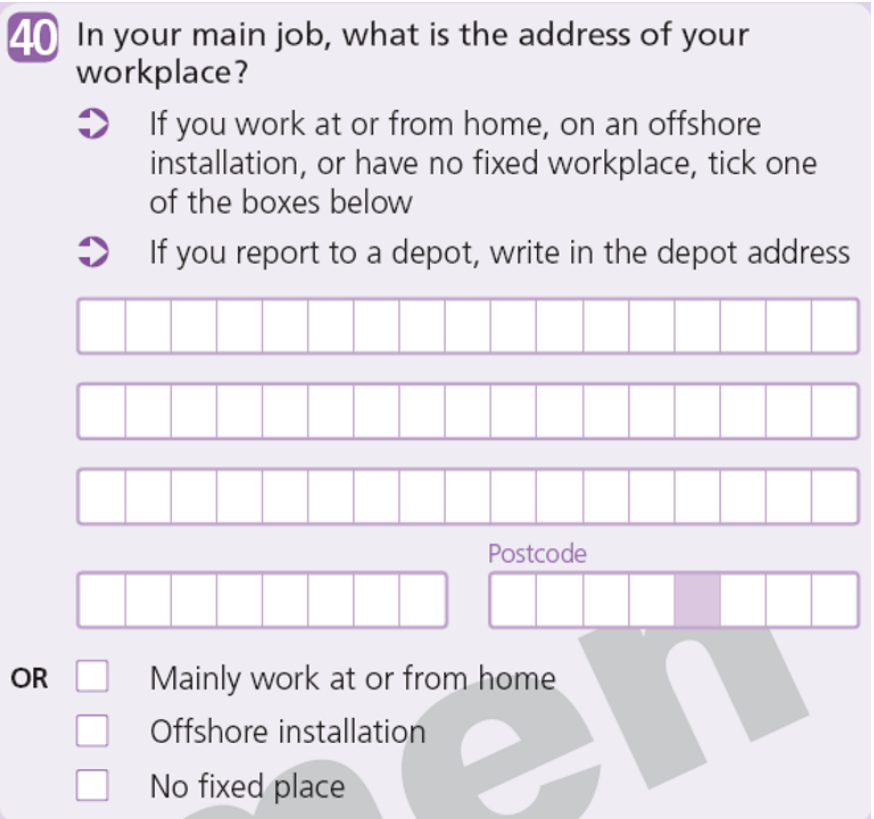

\section{Figure $6 \quad$ Work place address question, 2011 Census}

\section{(a) Scotland}

11 What address do you travel to for your main job or course of study (including school)?

- Answer for the place where you spend the most time.

- If you report to a depot, please write in the depot address.

Not currently working or studying $\rightarrow$ Go to 13

Work or study mainly at, or from, home $\rightarrow$ Go to 13 No fixed place

Work on an offshore installation - please use the address panel below to write in where you travel offshore from, for example "ABERDEEN HARBOUR"

The address below, please write in

\section{(b) Northern Ireland}

43 What address do you travel to for your main job or course of study (including school)?

$\rightarrow$ Answer for the place where you spend the most time.

$\checkmark$ If you report to a depot, write in the depot address. Not currently working or studying $\Rightarrow$ Go to 45 Work or study mainly at or $\Rightarrow$ Goto 45 from home

No fixed place

Offshore installation

The address below, write in

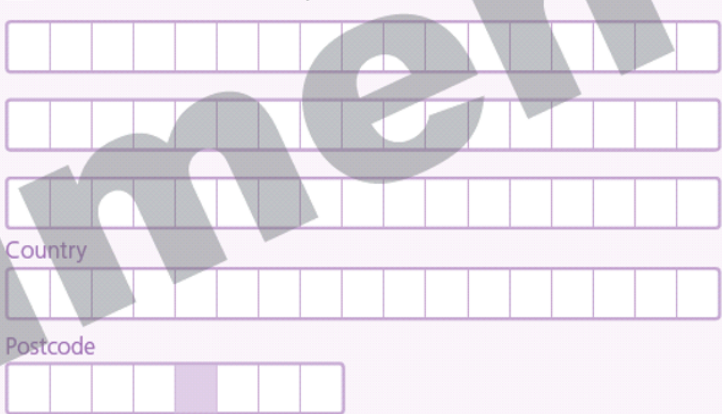

Similar output was produced for $2001^{9}$. In 2001 the workday population was known as the 'daytime' population. The change from 'daytime' to 'workday' population reflects a recognition that in a '24/7' economy many people work outside normal daytime hours. 
The workday population provides a measure of areas which at times of the day may have very high numbers of people in them, but where relatively few people actually live, for example, the City of London. This gives an indication of the level of service provision needs for those areas beyond that given by the usual residence population.

Both Scotland and Northern Ireland collect place of study as well as place of work. They could therefore produce a work and study place population. England and Wales only collect place of work. For the UK, therefore, workday/workplace populations will be produced, but Scotland and Northern Ireland may produce work and study day/ work and study place populations too.

\section{Out-of-Term population}

The out-of-term population is defined by placing students who are counted as being resident at boarding school or their university residence address back in their family home (if they have one). It will be produced for the usually resident population; that is, those intending to be resident in the UK for 12 months or more. Effectively, it is a geographical redistribution of the usually resident population who are students to their family home, if they have one. This will be achieved using the second address question obtained from their full enumeration at their term-time address (for more information on the second address question see below).

Similar output was produced for $2001^{10}$. However, total populations for an area were not presented in 2001 , only the numbers of students who would reside in an area. This was produced using the partial enumeration of students at their home address. No cross tabulation was produced showing term-time address by out-of-term address. It is planned that the 2011 Census will show an out-ofterm population for areas that will include students at their family home, and exclude students in the area of their term-time address (unless that is also their home address). The above output is only possible for England and Wales as Scotland and Northern Ireland do not have a second residence question. Outputs similar to those produced in 2001 can be obtained for the UK by using the questions which ask whether the person being enumerated is a schoolchild or student in fulltime education, and the following question which records whether they study away from that address. However to produce a full out-of-term population assumptions would have to be made in Scotland and Northern Ireland about where these students are in the usual residence base as there is no second address question on their questionnaire.

Calculating an out-of-term population meets the need to understand the important contribution that student movements make to the geographical distribution of the UK population. It would also be possible to calculate family statistics on a different basis, by including students back with their families (given that students are included in the relationship matrix at their home address).

There may be interest in applying this geographical redistribution to those in the overseas shortterm immigrant base to give a workplace population based on the entire enumeration base. This will only be considered once the quality of the overseas short-term immigrant base is assessed.

\section{Other Potential Output Bases}

There is the potential to produce a 'majority of time' base from the 2011 Census for England and Wales. For the first time in the England and Wales Census, information is being collected on whether respondents have an address elsewhere at which they spend at least 30 days a year, and 
the reason they live at that address. This information will help to understand how Census population estimates may relate to administrative data sources. For example, some city areas may have high numbers of properties that are used as second homes by workers whose usual residence is elsewhere. These people are likely to appear on local administrative data sources but will not be counted in the local usually resident population. Local authorities also want information on the purpose of the second residence to gain a better understanding of the uses made of their housing stock $^{11}$. The question is shown in Figure 7 below.

Question testing in the design phase for the 2011 Census suggested that it was not possible to define a self completion question easily for length of time spent at a second address, in particular because of the diverse patterns of time use - with some second addresses being used for a few days each week and others for longer blocks of time ${ }^{12}$.

\section{Figure 7 Question on second residence, 2011 Census, England and Wales}

5 Do you stay at another address for more than 30 days a year?

\section{No $\Rightarrow$ Goto 7}

Yes, write in other UK address below

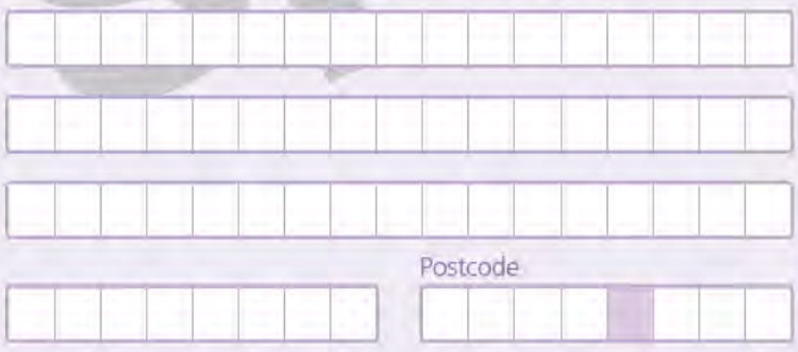

OR

Yes, outside the UK, write in country

6 What is that address?

Armed forces base address

Another address when working away from home

Student's home address

Student's term time address

Another parent or guardian's address

Holiday home

Other

The lack of information on time spent makes it more difficult to use the second residence question to create an alternative 'majority of time' population base. A crude assumption could be made that those whose reason for the second address is that it is an Armed Forces base address or another address when working, could be assumed to spend the majority of time at their second address. A more refined version would be to model what proportions of people spend the majority of time at the second address for each reason recorded. One potential source of the information required for 
this is the Census Coverage Survey (CCS). As this is an interviewer based survey it is easier to ask questions about time. The survey includes a similar (but not identical) question to the Census second residence question and an extra split has been included for time spent to state whether in a year it is greater than or less than 6 months. The question is shown at Figure 8.

\section{Figure $8 \quad$ Question on other address, England and Wales 2011 Census Coverage Survey}

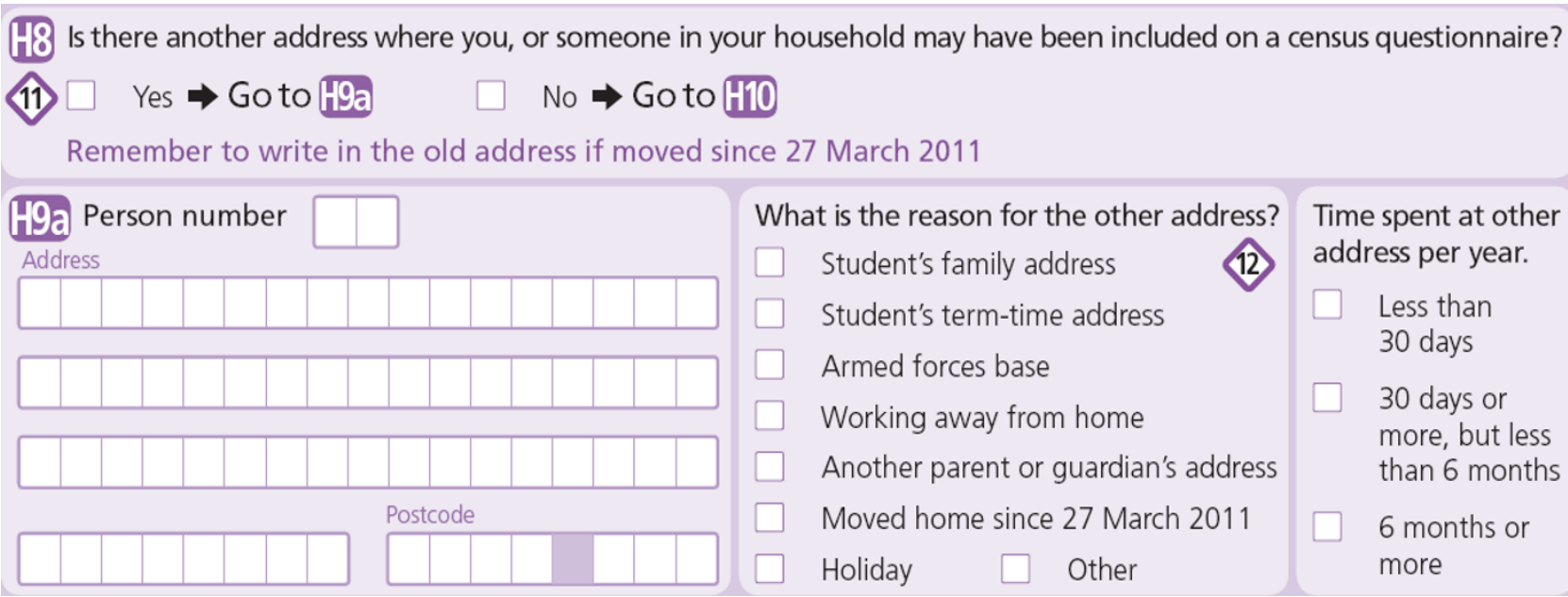

A decision on whether and how to produce a majority of time base will not be taken until after the Census is complete. Assessment can then be made of how both the Census and the CCS questions on second residence have performed, and how the information collected from both sources compares. The information in the CCS will be of value in that it will give a general indication at a high geographical level of the proportion of people in each of the 'time spent' groups.

\section{How the 2011 Census enumeration base was selected}

To assist in deciding who to enumerate, and which population subgroups need to be separately identified, a population matrix was created. This divided up all the potential groups that could be enumerated. Rough estimates of the size of these groups were also made to assess their relative impacts. The matrix divides the population by country of birth, UK or non -UK ${ }^{13}$. Having divided the population into these two groups, these groups were each subdivided into whether present or absent on Census night, how long they had already been present or absent, and how long their overall intended presence/absence would be. Using various data sources, including 2001 Census, the International Passenger Survey, and the Labour Force Survey (LFS), rough estimates were then made of the size of each resulting category to help determine whether the group should be separately identified. Note that the information in Table 2 relates to the UK.

Table 2 shows an edited version of the matrix, highlighting through shaded cells the groups that are identifiable in the 2011 Census in England and Wales, and through different colours whether they are separately identifiable. It also shows (highly rounded to the nearest 50,000 with indications of non zero values below 25,000) indicative numbers based on data from 2009 . 


\section{Table 2 Matrix of population showing groups that are captured, their estimated size and whether the Census can separately identify them, United Kingdom}

\begin{tabular}{|c|c|c|c|c|c|c|c|}
\hline & \multirow[b]{2}{*}{$\begin{array}{l}\text { Time to } \\
\text { census } \\
\text { date }\end{array}$} & \multirow[b]{2}{*}{$\begin{array}{l}\text { Intention (total } \\
\text { intended length } \\
\text { of stay in EW for } \\
\text { present/ abroad } \\
\text { for absent) }\end{array}$} & \multicolumn{2}{|c|}{$\begin{array}{l}\text { Defined to complete } \\
\text { Census as: }\end{array}$} & \multirow[b]{2}{*}{$\begin{array}{l}\text { Shaded } \\
\text { grouping of } \\
\text { cells that } \\
\text { can be } \\
\text { counted* }\end{array}$} & \multirow[b]{2}{*}{$\begin{array}{r}\text { Estimate } \\
\text { rounded to } \\
\text { nearest } 50,000 \\
\text { based on } 2007 \\
\text { figures }(000 \mathrm{~s}) \\
\end{array}$} \\
\hline & & & & Resident & Visitor & & \\
\hline \multirow{20}{*}{ UK Born } & \multirow{10}{*}{ Present } & $12 m+$ & & $\mathrm{Y}$ & & & 52,750 \\
\hline & & \multirow{2}{*}{$6-12 m$} & $>12 m$ & $Y$ & & & 50 \\
\hline & & & $<12 \mathrm{~m}$ & $Y$ & & & $<25$ \\
\hline & & \multirow{3}{*}{$3-6 m$} & $>12 \mathrm{~m}$ & $Y$ & & & $<25$ \\
\hline & & & $6-12 m$ & $\mathrm{Y}$ & & & $<25$ \\
\hline & & & $<6 \mathrm{~m}$ & $Y$ & & & $<25$ \\
\hline & & \multirow{4}{*}{$<3 m$} & $>12 m$ & $Y$ & & & $<25$ \\
\hline & & & $6-12 m$ & $Y$ & & & $<25$ \\
\hline & & & $3-6 m$ & $Y$ & & & $<25$ \\
\hline & & & $<3 m$ & & $Y$ & & \\
\hline & \multirow{10}{*}{ Absent } & $12 m+$ & & & & & \\
\hline & & \multirow{2}{*}{$6 m+$} & $>12 m$ & & & & \\
\hline & & & $6-12 m$ & $Y$ & & & $<25$ \\
\hline & & \multirow{3}{*}{$3-6 m$} & $>12 m$ & & & & \\
\hline & & & $6-12 m$ & $\mathrm{Y}$ & & & $<25$ \\
\hline & & & $3-6 m$ & $Y$ & & & $<25$ \\
\hline & & \multirow{4}{*}{$<3 m$} & $>12 m$ & & & & \\
\hline & & & $6-12 m$ & $\mathrm{Y}$ & & & $<25$ \\
\hline & & & $3-6 m$ & $\mathrm{Y}$ & & & 50 \\
\hline & & & $<3 m$ & $Y$ & & & 1,650 \\
\hline \multirow{20}{*}{$\begin{array}{l}\text { Overseas } \\
\text { 'Citizens' } \\
\text { (defined } \\
\text { by } \\
\text { country of } \\
\text { birth) }\end{array}$} & \multirow{10}{*}{ Present } & $12 m+$ & & $\mathrm{Y}$ & & & 5,650 \\
\hline & & \multirow{2}{*}{$6-12 m$} & $>12 m$ & $\mathrm{Y}$ & & & 250 \\
\hline & & & $<12 \mathrm{~m}$ & $Y$ & & & 50 \\
\hline & & \multirow{3}{*}{$3-6 m$} & $>12 m$ & $Y$ & & & 150 \\
\hline & & & $6-12 m$ & $Y$ & & & 50 \\
\hline & & & $<6 \mathrm{~m}$ & $Y$ & & & 50 \\
\hline & & \multirow{4}{*}{$<3 m$} & $>12 m$ & $Y$ & & & 150 \\
\hline & & & $6-12 m$ & $Y$ & & & 50 \\
\hline & & & $3-6 m$ & $\mathrm{Y}$ & & & 100 \\
\hline & & & $<3 \mathrm{~m}$ & & $\mathrm{Y}$ & & \\
\hline & \multirow{10}{*}{ Absent } & $12 m+$ & & & & & \\
\hline & & \multirow{2}{*}{$6 m+$} & $>12 \mathrm{~m}$ & & & & \\
\hline & & & $6-12 m$ & $\mathrm{Y}$ & & & $<25$ \\
\hline & & \multirow{3}{*}{$3-6 m$} & $>12 m$ & & & & \\
\hline & & & $6-12 m$ & $\mathrm{Y}$ & & & $<25$ \\
\hline & & & $3-6 m$ & $\mathrm{Y}$ & & & $<25$ \\
\hline & & \multirow{4}{*}{$<3 m$} & $>12 m$ & & & & \\
\hline & & & $6-12 m$ & $\mathrm{Y}$ & & & $<25$ \\
\hline & & & $3-6 m$ & $\mathrm{Y}$ & & & $<25$ \\
\hline & & & $<3 m$ & $Y$ & & & 200 \\
\hline
\end{tabular}

Note: *shaded cells indicate those enumerated in Census. Colours indicate which cells are grouped together, that is where more than one cell is shaded the same colour the individual cell values will not be separately identifiable. 
There are a number of groups that will be enumerated but are not individually identifiable given the Census questions. In particular, UK born short-term immigrants (those that are now resident abroad but return to the UK for less than a year) will be enumerated among the usual residents. This resulted from the need to avoid asking large numbers of people their year and month of arrival since most UK born will have never left the UK other than for holidays or short visits abroad. The UK born short-term immigrants are estimated to be a very small group, below 50 thousand a year, but may end up contributing to overcount in the 2011 Census.

It will also not be possible to identify separately those who are abroad for less than twelve months. There is no requirement to identify this group separately for outputs. However, this group is at risk of not being captured; being unable to identify this group separately makes reconciliation of the Census results with other sources more difficult. There are around 2.6 million short-term emigrant flows each year ${ }^{14}$ (although the stock of short term emigrants abroad at any one time will be considerably lower than this).

\section{How do the bases planned relate to previous thinking?}

The article by Smith and Jefferies ${ }^{2}$ outlined many potential population groups and bases that had been initially considered in an ONS report called Demographic Statistics for the 21st Century ${ }^{15}$. Table 2 in the article by Smith and Jefferies summarised which bases might be derived for the 2011 Census, given the thinking at that time. The first two columns of that table are reproduced in Table 3, with a third column stating the final position reached.

\section{Table 3 Potential output bases, view in 2006 and outcome for 2011}

\begin{tabular}{|l|l|l|l|}
\hline \multicolumn{2}{|l|}{ Output Base } & $\begin{array}{l}\text { Potentially available from } \\
2011 \text { Census? As described } \\
\text { in 2006 }\end{array}$ & Availability from 2011 Census \\
\hline 1. & $\begin{array}{l}\text { Usual residence - the population at } \\
\text { the address at which they usually } \\
\text { live. }\end{array}$ & Yes - planned & Yes - planned \\
\hline 2. & $\begin{array}{l}\text { Household population - the } \\
\text { population living in private } \\
\text { households. }\end{array}$ & Yes - planned & Yes - planned \\
\hline 3. & $\begin{array}{l}\text { Communal population - the } \\
\text { population living in communal } \\
\text { establishments. }\end{array}$ & Yes - planned & Yes - planned \\
\hline 4. & $\begin{array}{l}\text { Out of term population - the } \\
\text { population usually resident in an } \\
\text { area out of term-time. }\end{array}$ & $\begin{array}{l}\text { Yes (possible; would need to } \\
\text { sktudents and boarding } \\
\text { school pupils for their vacation } \\
\text { address, if different). }\end{array}$ & Yes - planned \\
\hline 5. & $\begin{array}{l}\text { Seasonal population - either the } \\
\text { usually resident population at } \\
\text { different times of year or enhanced } \\
\text { to include visitors (for example, } \\
\text { tourists). }\end{array}$ & No & No \\
\hline
\end{tabular}




\begin{tabular}{|c|c|c|c|}
\hline \multicolumn{2}{|c|}{ Output Base ${ }^{15}$} & \multirow{2}{*}{$\begin{array}{l}\text { Potentially available from } \\
2011 \text { Census? As described }^{2} \\
\text { in } 2006^{2}\end{array}$} & \multirow[b]{2}{*}{\begin{tabular}{|l} 
Availability from 2011 Census \\
No. There will be no way of \\
determining those who are \\
enumerated but who are actually \\
away from EW on Census night. \\
Therefore a true de facto population \\
cannot be produced. \\
The addition of the estimated usual \\
resident population plus the estimated \\
short-term migrant population plus the \\
count of visitors in an area less the \\
number of visitors that are in another \\
area would give an approximation of \\
the maximum de facto population in \\
terms of people present.
\end{tabular}} \\
\hline 6. & $\begin{array}{l}\text { De facto population - population } \\
\text { present on Census night. }\end{array}$ & & \\
\hline 7. & $\begin{array}{l}\text { Legal population - any 'legal' } \\
\text { definition of the population to serve } \\
\text { a particular purpose. }\end{array}$ & No & $\begin{array}{l}\text { Population by citizenship will be } \\
\text { produced as information about } \\
\text { passports is being collected. }\end{array}$ \\
\hline 8. & $\begin{array}{l}\text { Week-day population - population } \\
\text { usually resident/present overnight } \\
\text { during the week (for example, } \\
\text { Monday to Thursday nights). }\end{array}$ & $\begin{array}{l}\text { Possible. Could be estimated } \\
\text { for } 2011 \text { if secondary residence } \\
\text { data available (address plus } \\
\text { purpose or frequency of stay). } \\
\end{array}$ & $\begin{array}{l}\text { No }- \text { there is insufficient information on } \\
2^{\text {nd }} \text { residences to identify day of use. }\end{array}$ \\
\hline 9. & $\begin{array}{l}\text { Weekend population - population } \\
\text { usually resident/present at the } \\
\text { weekend (for example, Friday night } \\
\text { to Sunday). }\end{array}$ & $\begin{array}{l}\text { Possible. Similar to usual } \\
\text { residence under proposed } \\
\text { Census definition if Census day } \\
\text { is on a weekend; quality of } \\
\text { estimate for } 2011 \text { would be } \\
\text { improved if secondary } \\
\text { residence data available } \\
\text { (address plus purpose or } \\
\text { frequency of stay). }\end{array}$ & $\begin{array}{l}\text { A weekend usual resident population } \\
\text { cannot be calculated for the same } \\
\text { reason as a weekday population } \\
\text { cannot be calculated. }\end{array}$ \\
\hline 10. & $\begin{array}{l}\text { Temporarily resident population - } \\
\text { those present in an area but are not } \\
\text { usually resident there (for example, } \\
\text { children whose time is divided } \\
\text { between households, temporary } \\
\text { migrant workers). }\end{array}$ & $\begin{array}{l}\text { Yes - planned. Available from } \\
\text { visitor data but accuracy of this } \\
\text { base would be dependent on } \\
\text { the quality of visitor information } \\
\text { collected in } 2011 .\end{array}$ & \begin{tabular}{|l} 
Yes but not as a single figure and \\
quality of visitor information will need \\
to be assessed. \\
- $\quad$ Counts of visitors in an area \\
will be available \\
- Information on numbers of \\
people (including children) \\
with a second residence in \\
an area will be available \\
Information on numbers of \\
overseas born short-term \\
immigrants will be available \\
\end{tabular} \\
\hline 11. & $\begin{array}{l}\text { Work-day population - population } \\
\text { present in an area during normal } \\
\text { working hours Monday to Friday. }\end{array}$ & $\begin{array}{l}\text { Possible. Could be partly } \\
\text { estimated from workplace data. } \\
\text { Place of study data also needed } \\
\text { for the full picture. }\end{array}$ & $\begin{array}{l}\text { Yes for working population. Work and } \\
\text { study population potentially available } \\
\text { for Scotland and Northern Ireland. }\end{array}$ \\
\hline 12. & $\begin{array}{l}\text { Average population - average of } \\
\text { various other population bases. }\end{array}$ & $\begin{array}{l}\text { Possible; dependent upon other } \\
\text { output bases available. }\end{array}$ & $\begin{array}{l}\text { It is possible to average any base } \\
\text { created, however ONS would be } \\
\text { cautious about how any result may be } \\
\text { interpreted. It is unlikely any average } \\
\text { would give a true reflection of person } \\
\text { years (the sum of the product of the } \\
\text { number of people by their time } \\
\text { present in the year) in an area over a } \\
\text { year. }\end{array}$ \\
\hline
\end{tabular}




\begin{tabular}{|c|c|c|c|}
\hline \multicolumn{2}{|c|}{ Output Base ${ }^{15}$} & \multirow{2}{*}{$\begin{array}{l}\text { Potentially available from } \\
2011 \text { Census? As described } \\
\text { in } 2006^{2}\end{array}$} & \multirow[b]{2}{*}{$\begin{array}{l}\text { Availability from } 2011 \text { Census } \\
\text { No information is available to } \\
\text { separately identify UK usual residents } \\
\text { who are abroad at the time of the } \\
\text { Census enumeration. } \\
\\
\text { Information will be collected on } \\
\text { second residence abroad; however, } \\
\text { this is unlikely to cover all who living } \\
\text { abroad temporarily (such as short- } \\
\text { term emigrants). }\end{array}$} \\
\hline 13. & $\begin{array}{l}\text { UK residents living abroad - } \\
\text { temporarily or for part of the time } \\
\text { (for example, international } \\
\text { commuters). }\end{array}$ & & \\
\hline 14. & $\begin{array}{l}\text { Non-UK residents living in the UK } \\
\text { - for example, visitors, short-term } \\
\text { migrants, international commuters. }\end{array}$ & $\begin{array}{l}\text { Yes - planned. Available from } \\
\text { visitor data but accuracy of this } \\
\text { base would be dependent on } \\
\text { the quality of visitor information } \\
\text { collected in } 2011 .\end{array}$ & $\begin{array}{l}\text { Yes but not as a single figure. } \\
\text { - Counts will be available on } \\
\text { visitors with an address } \\
\text { abroad } \\
\text { Overseas born short-term } \\
\text { immigrants resident for 3-12 } \\
\text { months } \\
\end{array}$ \\
\hline 15. & $\begin{array}{l}\text { Bespoke service populations - } \\
\text { target population for a specific } \\
\text { service/policy. }\end{array}$ & $\begin{array}{l}\text { Dependent upon nature of } \\
\text { output needed. }\end{array}$ & $\begin{array}{l}\text { Dependent upon nature of output } \\
\text { needed. }\end{array}$ \\
\hline New & $\begin{array}{l}\text { Majority of time population - } \\
\text { resident population enumerated } \\
\text { where they live for the majority of } \\
\text { time. }\end{array}$ & - & $\begin{array}{l}\text { Potentially able to produce using } \\
\text { second residence question and } \\
\text { information from CCS to model reason } \\
\text { for second residence and time spent } \\
\text { there. }\end{array}$ \\
\hline
\end{tabular}

\section{Mid-year population estimates on different bases}

Mid-year population estimates are produced each year by taking the census base, adding births, subtracting deaths, adding immigrants and subtracting emigrants (known as the cohort component method). At present it is planned that only the usual residence base will be used to create mid-year population estimates in the years following the 2011 Census.

If other bases were to be created by using the usual cohort component method of 'ageing on' population with addition of births, subtraction of deaths and addition of net migration, then each of these components would need to be on that alternative base definition. So, for example, ONS would need to know the place of employment of those who die to remove those people from the workday/place population, and ONS would also need to know where a person's previous and new place of work are if they change workplaces. Additionally, that information would need to be available for their patient register moves as it is this source that is used to produce internal migration data. Given the limited nature of information collected from birth and death registration, patient registration and on international migration, it is unlikely that sufficient information could be collected to make estimates on different bases.

\section{Conclusion}

The 2011 Census has been designed so that definitions of who should be counted are as clear as possible. With stricter definitions on who is enumerated, it is possible to divide the resulting estimated enumeration base into distinct population groups. This, together with plans to produce different population bases more formally, should benefit all who need to understand differences in population and resource use at sub-national level. This information will also assist ONS to 
understand why population figures on official definitions may differ from those given by administrative sources.

ONS has begun a programme of work entitled 'Beyond 2011'16 to consider whether Census and population estimate type information can be created using administrative sources. The new information collected in the 2011 Census will assist with this work. At present, a study is being planned to investigate administrative sources for those postcode areas covered by the Census Coverage Survey, thus permitting comparison with the best estimated population.

\section{Acknowledgements}

The author would like to acknowledge the helpful comments of colleagues in ONSCD, the devolved administrations and Census. In particular, the author wishes to thank Johanna Shaw for her work on the population matrix and also Kate Johnson and Emma Wright.

\section{References}

1 Lucy Baker (2004) 'Covering All Bases: early thoughts for population bases for the 2011 Census'. Population Trends 116: 6-10

2 Chris W Smith, Julie Jefferies (2006), 'Population bases and statistical provision: towards a more flexible future?' Population Trends 124: 18-25

3 Ian White, Elizabeth McLaren (2009) 'The 2011 Census taking shape: the selection of topics and questions', Population Trends 135: 8-19

4 See: www.ons.gov.uk/census/2011-census/2011-census-project/registrar-s-general-sagreement---october-2010-update.pdf

5 UK response to requirements of the UK Statistics Authority special assessment of the 2011 Censuses in the UK (2010) See: www.ons.gov.uk/census/2011-census/2011-censusproject/independent-assessments/uk-response-to-uksa-special-assessment---phase-one.pdf

62001 Census: Local Authority Population Studies Progress Review (2004) See: www.statistics.gov.uk/downloads/theme population/2001Censuslapopulationstudies.pdf

7 Owen Abbott (2009) '2011 UK Census Coverage Assessment and Adjustment Methodology', Population Trends 137: 25-32

8 Most of the population is only enumerated once. One exception to this is those who are away from their home address for study. Basic information on these people, including relationships to others in the household, age, sex, legal partnership status and second address, is collected at their home address, but a full enumeration is expected at their term-time address. A sample of students from their 'home address' and where a second address has been given will be checked with their term-time address to ensure they have been enumerated correctly. 
9 Table T10 'All people aged 16-74 who are either resident in the area or work in the area: Census 2001', National Report for England and Wales - Part 2 (produced to ward level). See: www.statistics.gov.uk/StatBase/ssdataset.asp?vlnk=7530\&Pos=\&ColRank=2\&Rank=272

10 Table S012 'All schoolchildren and students in full-time education who would reside in the area were they not living away from home during term-time: Census 2001', National Report for England and Wales - Part 2 (produced to ward level).See:

www.statistics.gov.uk/StatBase/ssdataset.asp?vlnk=7552\&Pos=\&ColRank=2\&Rank=256

11 See: www.ons.gov.uk/census/2011-census/collecting-info/dev-questionnaires/test-defs.pdf

12 See: www.ons.gov.uk/census/2011-census/2011-census-questionnaire-content/questionand-content-recommendations-for-2011/final-recommended-questions-2011---secondaddresses.pdf

13 In initial versions of the matrix the population was divided up by citizenship - UK vs non-UK. However, in order to filter the intention to stay question on the Census appropriately, the matrix evolved to the population being split by whether or not a person was UK born.

14 Mid-2009 Short-term Migration Estimates for England and Wales (February 2011) See: www.statistics.gov.uk/pdfdir/stmig0211.pdf

15 Office for National Statistics (2003) 'Demographic Statistics Service for the 21st Century'. See: www.statistics.gov.uk/about/methodology by theme/Dem Stat Ser 21ST Cen.asp

16 See: www.ons.gov.uk/about-statistics/methodology-and-quality/imps/beyond-2011/index.html 